\title{
CONTROL OF MANGE MITE, Sacroptes scabiei ON SHEEP Desoky,A.S.S. ${ }^{1}$; T. M. Abo-Elmaged, ${ }^{2}$ and H. A. Hamdon ${ }^{3}$ \\ Egypt. Abdelalem2011@yahoo.com \\ 1- Plant Protection Department (Zoology), Fac. Agric., Sohag University, \\ 2- Plant Protection Department, Fac. Agric,, Assiut University, Egypt tnmn203@yahoo.com \\ 3- Animal Production Department, Fac. Agric., Assiut University, The New Valley Branch, Egypt. \\ hamdon9@yahoo.com
}

\begin{abstract}
The present study was designed to determine the effect of seven chemicals used to control mange mite on sheep. These chemicals were (1) Mange cides $10 \%$, (2) Tincture idone 4\%, (3) Noromectin 1.0\% used once a month, (4) Noromectin $1.0 \%$ used twice a month, (5) Mange cides + skin recovery, (5) Noromectin 1.0\% injection + Mange cides and (7) Mange cides + skin recovery + Noromectin 1.0\% treated twice a month.

Sheep infected with scabies were responded to the healing of the disease when treated with the compounds mentioned above (i.e., Mange cide 10\%; Tincture idone $4 \%$; Norometcin $1.0 \%$ once a month and Noromectin $1.0 \%$ twice a month) are just $45,45,30$, and 20 days, respectively.

Keywords: Mange mite, Sarcoptes scabiei, sheep, mange cure, acaricides.
\end{abstract}

\section{INTRODUCTION}

Scabies is considered one of the most common skin disease that spread to humans and animals. This disease is caused by the itch mite, Sacroptes scabiei L.), this species is spread worldwide. There are several types of the scabies such as classical scabies, Norwegian scabies and clean scabies. However, classical scabies is very common in human and animals in Pakistan and many other countries. It has been reported that approximately several millions of humans and animal are affected by skin diseases including scabies (Hicks and Elston, 2009).

The gravid female of the parasite lays from 2 to 3 eggs day in burrows of the stratum corneum of epidermis. After 50-72 hours, the larvae emerge from eggs and make new skin burrows. The life cycle of Sacroptes scabiei from egg to adult emergence lasts about 10-17 days (Soulsby, 1982).

The bathing by water can be removed a significant numbers of the pest from humans and animals skin. However in appropriate bathing may affect the skin of both animal and human. Washing also may cause skin dryness and scratches and may harm the skin because dry skin is more proven to severe itching and irritation. In such conditions people and animals infected with Sacroptes scabiei may lead to other health problems such as; dermatitis, pyoderma and sometimes eczema and urticaria. Treatment of Sacroptes scabiei. However, oral application by using ivermectin is recommended for healing crusted scabies (Mounsey et al., 2008). On the other hand, 
permethrin used as topical cream has been successfully used for the treatment of scabies disease in Australia (Carapetis et al., 1997). However, a recent in vitro study on acaricidal sensitivity has demonstrated an increase tolerance of Sacroptes scabiei mites to permethrin collected from indigenous people communities across northern Australia (Mounsey et al., 2009). Several constraints such as resistance of Sacroptes scabiei to synthetic medicines may be due to the repeated use of the same mode of action medicines in the sick people and animals, the side effects of medicines, their unaffordable cost for some people and the long residual properties of most of the synthetic medicines available in the market justify the cause to find alternative approaches to control Sacroptes scabiei mite. The use of plant extracts might be useful to cope with scabies disease on human and animals.

The high national prevalence of sheep scab and pediculosis indicated that, current control methods are failing to contain these ectoparasites. The results of this study suggested that a large proportion of insecticide applications take place at times of year when they might expect to be relatively ineffective, and the use of inappropriate compounds for the parasites in question in common. The widespread use of macrocylic lactones in particular for scab prevention and control is of concern, because of the additional use of these compounds in parasitic worm control and the potential that their overuse will hasten the development of resistance (Betty and Richard, 2008).

\section{MATERIALS AND METHODS}

The present work was carried out at sheep farm in the Experimental Station of the Faculty of Agriculture, El-Kawther city, Sohag University during 2013 year. This station is located in the newly reclaimed area at the eastern desert (15 km east of Sohag Governorate).

materials:

Sheep infested with Sacroptes spots were treated with the following

- Mange cides $10 \%$.

- Tincture idone $4 \%$.

- Noromectin $1.0 \%$ once a month ( $1 \mathrm{ml}$ injection $/ 50 \mathrm{~kg}$ of animal).

- Noromectin 1.0\% twice a month (1 ml injection/50 kg of animal).

- Mange cides + skin recovery.

- Normectin $1.0 \%$ injection + Mange cides.

- Mange cides + skin recovery + Normectin 1.0\% (twice a month).

Each transaction of these materials referred to above are used for three sheep. According to the skin injury, the animals were classified as follows:

1-Heavily infested animals $(+++)$.

2-Moderately infested animals $(++)$.

3-Slightly infested animals (+).

4-No infested animals and the wool started to cure (-).

5-Normal skin and wool (N).

The observations were taken after 1, 3, 5, 7, 10, 15, 20 and 25 days. 


\section{Treatments:}

1- Mange cides (Benzyle benzoate, Salicylic acid, Sulphur, Phenol, Tar)

2- Tincture idone $4 \%$.

3- Noromectin $1.0 \% \mathrm{w} / \mathrm{v}$

The materials used are characterized as colorless, clear, slightly viscous, sterile, non aqueous solution containing $1.0 \% \mathrm{w} / \mathrm{v}$ ivermectin with a wide safety margin and no adverse effect on breeding performance.

These materials were manufactured by Norbrok Laboratories Limited, Newry, N Ireland, BT35 6JP, and the chemical group is macrocyclic lacton (Ivermectins) that used as injection.

\section{RESULTS AND DISCUSSION}

Data in Table (1) show the effect of materials used to control mange mites infesting sheep. The treatment with Mange cides, Tincture idone, Normoectin $1.0 \%$ once a month and Noromectin $1.0 \%$ twice a month, revealed that the treated animals with Mange cides and Tincture idone began to respond after 45 days, this may be due mainly to blocking oxygen from the mite. When used Noromectin 1\% (injection) (one a month) and Noromectin $1 \%$ (injection) twice a month, they gave satisfactory results after 30 and 20 days of treatment, this may be due to the effect of ivermectin paralysis and ultimately kills parasitic nematode arachnids and insects by their effects on the nervous systems of these parasities, with adverse effect on the husbandry animals.

Table (1): Effect of Mange cides; Tincture idone; Noromectin 1.0\% (once) and Noromectin $1.0 \%$ (twice) on sheep mange under field conditions, during 2013/2014.

\begin{tabular}{|c|c|c|c|c|}
\hline \multirow{2}{*}{$\begin{array}{c}\text { Treated } \\
\text { materials }\end{array}$} & $\begin{array}{c}\text { Mange cides } \\
\text { Method (1) }\end{array}$ & $\begin{array}{c}\text { Tincture idone } \\
\text { Method (2) }\end{array}$ & $\begin{array}{c}\text { Noromectin 1.0\% } \\
\text { (once a month) } \\
\text { Method (3) }\end{array}$ & $\begin{array}{c}\text { Noromectin 1.0\% } \\
\text { (twice a month) } \\
\text { Method (4) }\end{array}$ \\
\cline { 2 - 5 } & $\mathrm{N}=3$ & $\mathrm{~N}=3$ & $\mathrm{~N}=3$ & $\mathrm{~N}=3$ \\
\hline 1 & +++ & +++ & +++ & +++ \\
\hline 3 & +++ & +++ & ++ & ++ \\
\hline 5 & ++ & +++ & + & + \\
\hline 7 & ++ & ++ & - & - \\
\hline 10 & + & ++ & - & - \\
\hline 15 & + & + & - & $\mathrm{N}$ \\
\hline 20 & - & + & $\mathrm{N}$ & $\mathrm{N}$ \\
\hline 30 & - & - & $\mathrm{N}$ & $\mathrm{N}$ \\
\hline 45 & - & - & & \\
\hline
\end{tabular}

Sings:

Heavily infested animals (+++).

Moderately infested animals (++).

Slightly infested animals (+).

No infested animals and the wool started to cure (-).

Normal skin and wool (N).

These results coincided with those obtained by Ibrahim (1994) when used Diazinon and Ivermectin on infested sheep, he found that the mean time for recovery was 26.4 days in animals treated with Diazinon and 28.4 days in 
Ivermectin treatments. In general, sheep treated with Ivermectin take lesser time to recover than in Diazinon treatment. Cozma et al. (2010) in a study of three acaricides, Doramectin (Dectomax, Pfizer) used at a single dose of 300 $\mu \mathrm{g} / \mathrm{kg}$ (b.w.) given intramuscularly showed high efficacy (95\%) against Psoroptes ovis, in naturally infected sheep. All Doramectin treated animals were clinically normal and all skin scrapings were negative for mites 50 days after treatment. At the end of experiment (70 days) only $5 \%$ of the animals showed skin lesions and low infestation score $(1+)$, compared to $10 \%$ for Ivermectin.

Data in Tables (2 and 3) showed the effect of the treatment of sheep with mixed of Mange cides + skin recovery the animals, began to respond after 30 days, 20 days for Mange cides + Noromectin 1.0\% injection (once and twice a month) and 10 days for Mange cides + recovery + Noromectin $1.0 \%$ injection (twice a month), wholly in agreement with Witmer et al. (1995), Abo Elmaged (1998), Hagawane et al. (2010) and Desoky (2011) who found that, the best results in controlling scabies were obtained when used Ivermectin injection mixed with sulfur on body surface of sheep infested with mange. Ivermectin injection is the best way to control animals mane when sprayed on animals. Also, where used as Injection 9twice a month) it gave a satisfactory results as compared with once a month.

Table (2): Effect of Mange cides; Tincture idone; Noromectin 1.0\% (once) and Noromectin $1.0 \%$ (twice) on sheep mange under field conditions, during 2013/2014.

\begin{tabular}{|c|c|c|c|}
\hline \multirow{2}{*}{$\begin{array}{r}\text { Treated } \\
\text { materials }\end{array}$} & $\begin{array}{c}\text { Mange cides + skin } \\
\text { recovery } \\
\text { Method (5) }\end{array}$ & $\begin{array}{c}\text { Mange cides + } \\
\text { Noromectin 1.0\% } \\
\text { injection } \\
\text { Method (6) }\end{array}$ & $\begin{array}{c}\text { Mange cides + recovery } \\
\text { + Noromectin 1.0\% } \\
\text { injection (twice month) } \\
\text { Method (7) }\end{array}$ \\
\cline { 2 - 5 } & $\mathrm{N}=3$ & $\mathrm{~N}=3$ & $\mathrm{~N}=3$ \\
\hline 1 & +++++ & + \\
\hline 3 & ++ & ++ & + \\
\hline 5 & ++ & + & $\mathrm{N}$ \\
\hline 7 & + & + & $\mathrm{N}$ \\
\hline 10 & - & - & $\mathrm{N}$ \\
\hline 15 & - & - & $\mathrm{N}$ \\
\hline 20 & - & $\mathrm{N}$ & $\mathrm{N}$ \\
\hline 30 & $\mathrm{~N}$ & $\mathrm{~N}$ & $\mathrm{~N}$ \\
\hline 45 & $\mathrm{~N}$ & & + \\
\hline Sings: & & & ++ \\
\hline
\end{tabular}

Heavily infested animals (+++).

Moderately infested animals (++).

Slightly infested animals (+).

No infested animals and the wool started to cure (-).

Normal skin and wool (N). 
Table (3): Mean time in days for treated sheep by some chemicals to recover from scabies during 2013/2014.

\begin{tabular}{|l|c|}
\hline Treatment $\quad$ Infestation area| & $\begin{array}{c}\text { Mean time of skin recovery } \\
\text { (days) }\end{array}$ \\
\hline Mange cides & 45 \\
\hline Tincture idone & 45 \\
\hline Noromectin 1.0\% (once a month) & 30 \\
\hline Noromectin 1.0\% (twice a month) & 20 \\
\hline Mange cides + skin recovery & 30 \\
\hline Mange cides + Noromectin 1.0\% injection & 20 \\
\hline $\begin{array}{l}\text { Mange cides + skin recovery + noromectin } \\
1.0 \% \text { injection (twice a month) }\end{array}$ & 10 \\
\hline
\end{tabular}

\section{CONCLUSION}

In general, the best method for controlling sheep mange is the method (1) when used Mange cides + skin recovery + Noromectin 1.0\% injection (twice a month) on body surface of sheep, the skin of animal was completely healed in less time. This may be due to the presence of sulfur compound that prevent oxygen from mite.

The second method (2) when used Noromectin injection is the best way to control animals, it can be used twice a month; the Noromectin injection is highly effective against internal and external parasites at a dose volume of $1 \mathrm{ml} / 50 \mathrm{~kg}$ body weight.

\section{REFERENCES}

Abo Elmaged, T.M. (1998). Recent trends for controlling some harmful arthropods in the husbandry. M.Sc. Thesis, Fac. Agric., Assiut Univ., Assiut, Egypt.

Betty, B. and W. Richard (2008). Control and management of sheep mange and pediculosis in Great Britain. Veterinary Parasitology, 155: 120-126.

Carapetis, J.R.; C. Connors; D. Yarmirr; V. Krause and B.J. Currie (1997). Paediatric. Infect. Dis. J., 16 (5): 494-499.

Cozma, V.; E. Suteul; C. Ghermanl and B. Losson (2010). Therapy with avermectines and idazinon of psoroptic mange in sheep from Transylania, Romania. Sci Parasitol., 11 (2): 105-107.

Desoky, A.S.S. (2011). Studies on certain ectoparasites associated with some farm animals and their control. Ph.D. Thesis, Fac. Agric., Assiut Univ., Assiut, Egypt, 179 pp.

Hagawane, S.D.; G.R. Rajurkar and S.B. Shinde (2010). Ethno veterinary drug therapy for ear mange in sheep. Veterinary World, 3 (6): 295-296.

Hicks, M.I. and D.M. Elston (2009). "Scabies". Dermatologic therapy, 22 (4): 279-92.

Ibrahim, O.E. (1994). Control of skin parasites among sheep flocks. M.Sc. Thesis, Fac. Of Vet. Medicine, Cairo Univ., Cairo, Egypt, 70 pp. 
Desoky,A.S.S. et al.

Soulsby, E.J.L. (1982). Helminths, arthropods and protozoa of domesticated animals.

Mounsey, K.E.; D.C. Holt; J. McCarthy; B.J. Currie and S.F. Walton (2008). Future Microbial, 3 (1): 57-66.

Mounsey, K.E.; D.C. Holt; J. McCarthy; S. James; B.J. Currie and S.F. Walton (2009). Arch. Dermatol., 145 (7): 840-841.

Witmer, G.W.; M.W. Fall and L.A. Fiedler (1995). Rodent control, research needs, and technology transfer. International Wildlife Management Congress, 16-26.

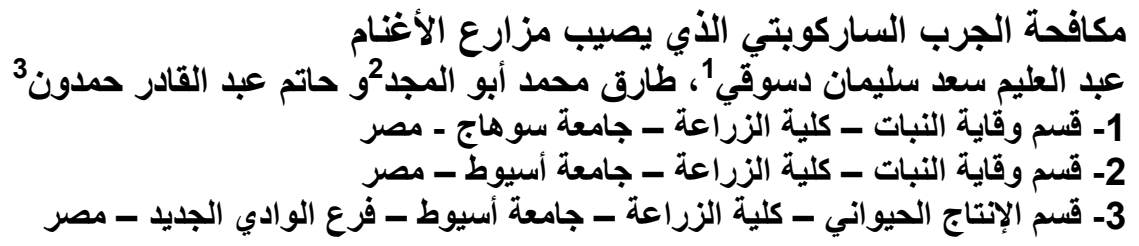

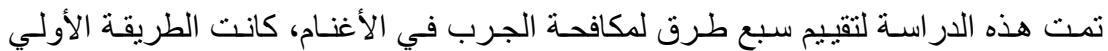

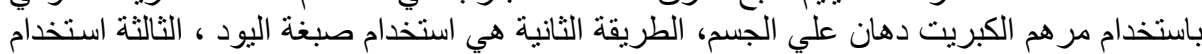

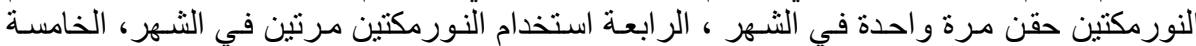

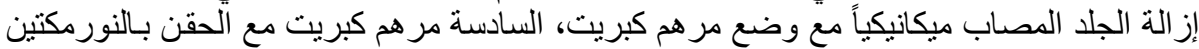

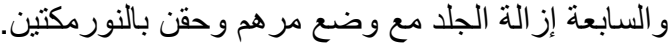

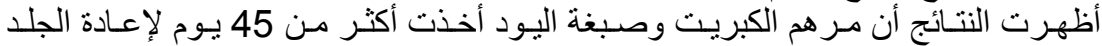

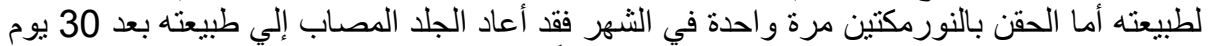

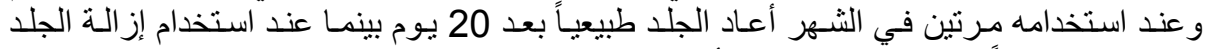

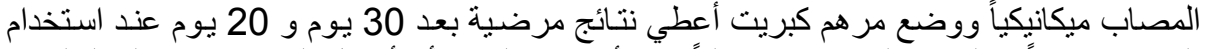

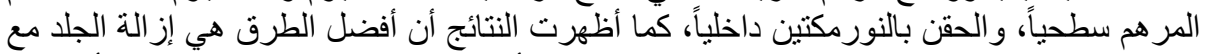

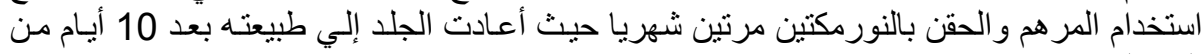

المعاملة 